\title{
High Performance Reinforced Concrete Beams made with Sandstone Reactive Aggregates
}

\author{
Paramasivam Suresh Kumar*,1, Md. Abdul Mannan*,2 and KurianVelluruzhathil John \\ Civil Engineering Program, School of Engineering and Information Technology, Universiti Malaysia Sabah, 88999 \\ Kota Kinabalu, Malaysia
}

\begin{abstract}
An investigation on the flexural behaviour of reinforced high performance concrete (HPC) has been conducted. Crushed sandstone known as reactive aggregate was used for both fine and coarse aggregates. In addition, mineral admixtures such as silica fume and fly ash combined with superplasticiser was used. The beams were made with concrete having compressive strength in the range of $74-88 \mathrm{~N} / \mathrm{mm}^{2}$ and tensile reinforcement in the range of 1.34 to $3.14 \%$. The experimental ultimate moment was found to be about $14-34 \%$ and $3-15 \%$ higher than the predicted ultimate moment based on BS 8110 and ACI 318 respectively. Due to lower stiffness of reactive sandstone aggregates, the actual deflections of the beams were found to be slightly above allowable values under service loads. The observed crack widths under service loads were within acceptable limits. It was found that HPC made with crushed sandstone coarse and fine aggregate had better structural integrity. Hence, there is a high potential to produce high strength HPC using sandstone aggregates with silica fume and fly ash.
\end{abstract}

Key Words: High performance concrete, Sandstone aggregate, Deflection, Crack, Ductility, Neutral axis.

\section{INTRODUCTION}

Although HPC has found widespread structural application, its production is still limited in many countries due to shortage of quality materials. As sources of quality concrete aggregate become depleted, the use of more marginal aggregates results in an increased use of reactive aggregates in concrete. At present, more than $54 \%$ of the local construction in Sabah, Malaysia uses sandstone as coarse aggregate for normal strength concrete. It is known that the certain reactive silica present in the sandstone reacts with the alkalis from cement paste and external sources [1]. This causes serviceability problem in concrete structures. Many local concrete structures have deteriorated due to reaction caused by sandstone aggregate, even at early ages.

Normally, the coarse aggregate used in HPC should be hard, dense, non-reactive and durable. However, the sandstone aggregates are porous and reactive [2]. It was reported by Baalbaki et al., [3] that the concrete made with soft aggregates like sandstone with relatively low modulus of elasticity exhibited low modulus of elasticity and high compressive strength. According to Neville[4], the aggregate with low modulus of elasticity would be more beneficial with respect to HPC. It is widely accepted that incorporation of mineral admixtures in concrete enhances the engineering properties particularly in areas where high quality aggregates are not available $[5,6]$.

Collins et al., [7] have reported that the porous aggregates such as sandstone are less susceptible for reaction. In general, HPC is designed with very low water-binder ratio. At low water-binder ratio, the effect of self-desiccation may

*Address correspondence to this author at the Civil Engineering Program, School of Engineering and Information Technology, Universiti Malaysia Sabah, 88999 Kota Kinabalu, Malaysia; Tel: +6-088-320 000 (ext) 3100; Fax: +6-088-320348; E-mails: drpsuresh@hotmail.com, mannan@ums.edu.my reduce the moisture content to a level and minimise the aggregate expansion [8]. HPC typically contains significant amount of supplementary cementing materials that may reduce the alkalis in concrete pore solution. The aggregate reaction is delayed or minimized by lowering the alkalis in the concrete pore solution $[9,10]$. Since fine and coarse aggregates together constitute the major volume in concrete, it is important to ensure that both sources are of similar quality [11]. It was shown that up to $40 \%$ of river sand could be replaced effectively by crushed sandstone sand without compromising quality of HPC [12].

Most of the studies on flexural behaviour of high strength and high performance concrete beams [13-16] are made with non-reactive aggregate. Only few studies are available on flexural behaviour of beams using reactive aggregates. Swamy et al., [17] reported that the reduction of ultimate strength in a single reinforced beam amounted to about $25 \%$ and $15 \%$ for highly reactive aggregate and moderately reactive aggregate respectively. On the contradictory, it was shown by Fan and Hanson [18] that expansion and cracking caused by aggregate reaction did not reduce the flexural loading capacity of the beams. At the same time both studies reported that the mechanical properties such as compressive strength, modulus of rupture and elastic modulus of concrete reduced over a time. Alkali-aggregate reaction is a timedependent mechanism. At early ages the reactivity of sandstone aggregates are not recognised. This must be confirmed by investigation. However, this paper reports the results of an experimental investigation on flexural behaviour of high performance reinforced concrete (HPRC) beams made with reactive sandstone coarse and fine aggregates.

\section{MATERIALS}

Locally manufactured cement (Type I, ASTM) and commercially available powdered Silica fume (W.R.Grace brand) were used as binder. Sandstone coarse aggregate with $19 \mathrm{~mm}$ maximum size and river sand replaced with $40 \%$ 
Table 1. Detailed Mix Proportion for ${ }^{1 \mathrm{~m} 3}$ and Fresh Concrete Properties

\begin{tabular}{|c|c|c|c|c|}
\hline \multicolumn{2}{|c|}{ Material } & \multicolumn{3}{|c|}{ Quantity/Property } \\
\hline \multicolumn{2}{|c|}{ Silica fume, $\mathrm{kg}$} & -- & 37 & 38 \\
\hline \multicolumn{2}{|c|}{ Fly ash, kg } & -- & -- & 72 \\
\hline \multicolumn{2}{|c|}{ Water, kg } & 165 & 165 & 165 \\
\hline \multicolumn{2}{|c|}{ Sandstone coarse aggregate, $\mathrm{kg}$} & 1124 & 1077 & 1056 \\
\hline \multirow[t]{2}{*}{ Fine aggregate } & River sand, $\mathrm{kg}$ & 332 & 319 & 312 \\
\hline & Crushed sandstone sand, $\mathrm{kg}$ & 234 & 224 & 220 \\
\hline \multicolumn{2}{|c|}{ Air content $(\%)$} & 2.4 & 1.6 & 2.1 \\
\hline
\end{tabular}

crushed sandstone sand as fine aggregate were used. A superplasticiser (SP) of type-F (W.R.Grace brand) brown coloured aqueous solution without any chloride and with solid content between $40 \%$ and $41 \%$ was used. The dosage of SP was adjusted to obtain the desired workability. Sufficient mixing time was allowed to produce the homogenous concrete. The detailed mix proportions are shown in Table $\mathbf{1}$. Locally available deformed bars with yield strength in the ranges of $528 \mathrm{~N} / \mathrm{mm}^{2}$ to $534 \mathrm{~N} / \mathrm{mm}^{2}$ were used as tensile reinforcement. Shear reinforcement consisted of $6 \mathrm{~mm}$ and 8 $\mathrm{mm}$ diameter mild steel bars with yield strength of 250 $\mathrm{N} / \mathrm{mm}^{2}$.

\section{EXPERIMENTAL PROGRAM}

Nine simply supported reinforced HPC beams were tested under two point loading with a constant moment region. All beams were designed for a shear span (a) to depth ratio of 5.75 with constant effective depth of $200 \mathrm{~mm}$. The clear cover for the tested beams was maintained at $20 \mathrm{~mm}$. Each beam was designated using letters and numbers. The letter ' $C$ ' refers to the mix containing cement alone. Similarly the letters ' $\mathrm{CS}$ ' and 'CSF' refers to the mixes containing cement with silica fume and cement with silica fume and fly ash respectively. The numbers (1,2 and 3$)$ followed by the letter refers to the percentage of tension reinforcement ratios $1.34 \%, 2.10 \%$ and $3.14 \%$. The compression reinforcement ratio was fixed at about 0.33 for all beams. Typical reinforcement arrangement and geometry of the beam are shown in Fig. (1).

All the beams were cast in wooden moulds and the companion concrete specimens were cast in standard steel moulds. For each mix, three numbers of $100 \mathrm{~mm}$ cubes for compressive strength, two numbers of $\phi 150 \times 300 \mathrm{~mm}$ high cylinders for static modulus of elasticity and three numbers of $100 \mathrm{~mm} \times 100 \mathrm{~mm} \times 500 \mathrm{~mm}$ prisms for flexural strength were cast. Compaction was done using $\phi 25 \mathrm{~mm}$ needle vibrator for beams and vibrating table for companion concrete specimens. The beams and the companion concrete specimens were demoulded after 24 hours and were cured with wet hessian (spraying the water twice a day, similar to site curing being practiced in Malaysia) for 6 days. After that, the specimens were air-cured with relative humidity of $74-88 \%$ and ambient temperature $25 \pm 3^{\circ} \mathrm{C}$ until the age of testing.

The beams were instrumented with the LVDT (linear voltage displacement transducers) at mid-span to observe the deflection. Electrical strain gauges (PL-60) were used to measure the concrete strain at the surface in the pure bending region. Steel strains were measured using FLK 6-11 gauges with active grid length of $6 \mathrm{~mm}$. The steel strain gauges were covered with silicone gel to prevent accidental damage during casting. The crack width measurements were made using a hand-held microscope magnification of X 40 with an accuracy of $0.02 \mathrm{~mm}$. The end rotation was measured using digital theodolite with an accuracy of one second. The theodolite was positioned over the beam support $(100 \mathrm{~mm}$ from end face of beam) and the graduated staff was fixed at a predetermined distance to enable the vertical readings. Apart from this, a curvature meter was devised in this study using steel frame connected with LVDT's to measure the curvature in the pure bending region. The loading rate was maintained at a rate of $0.5 \mathrm{~mm} / \mathrm{min}$ until the specimen failed. Strains and deflection readings were recorded automatically using data logger during the test. Typical loading arrangement for the test beam is shown in Fig. (2).

\section{TEST RESULTS AND DISCUSSIONS}

\section{Mechanical Properties}

Structural properties such as compressive strength $\left(f_{c u}\right)$, flexural strength $\left(f_{r}\right)$ and static modulus of elasticity $\left(\mathrm{E}_{\mathrm{c}}\right)$ of the companion concrete specimens were tested at the same testing age of beams. Testing of companion concrete specimens was carried out in accordance with British Standards. Table 2 summarises the results of mechanical properties of the companion concrete specimens and reinforcement details of tested beams. The compressive strength of the mixes C, 


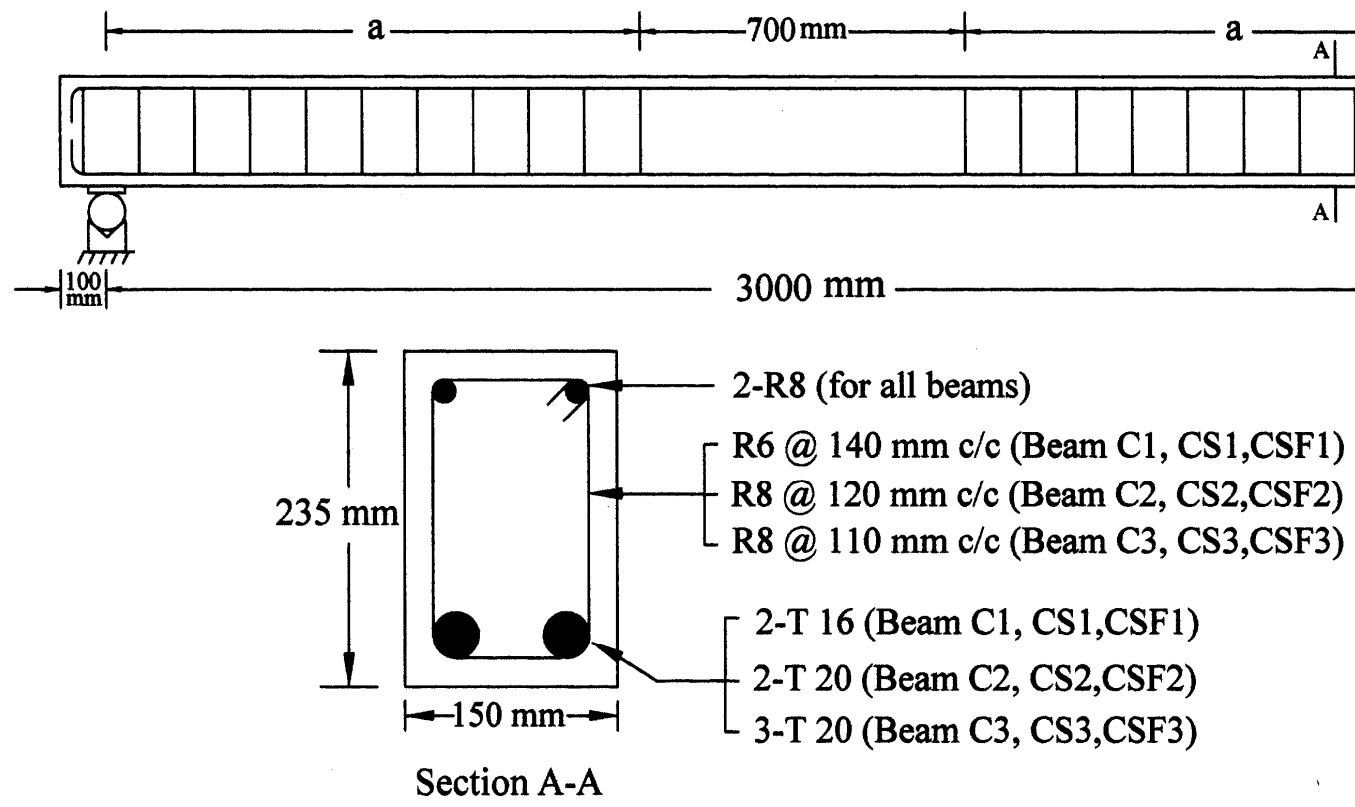

Fig. (1). Typical Reinforcement Arrangement and Geometry of the Beam.

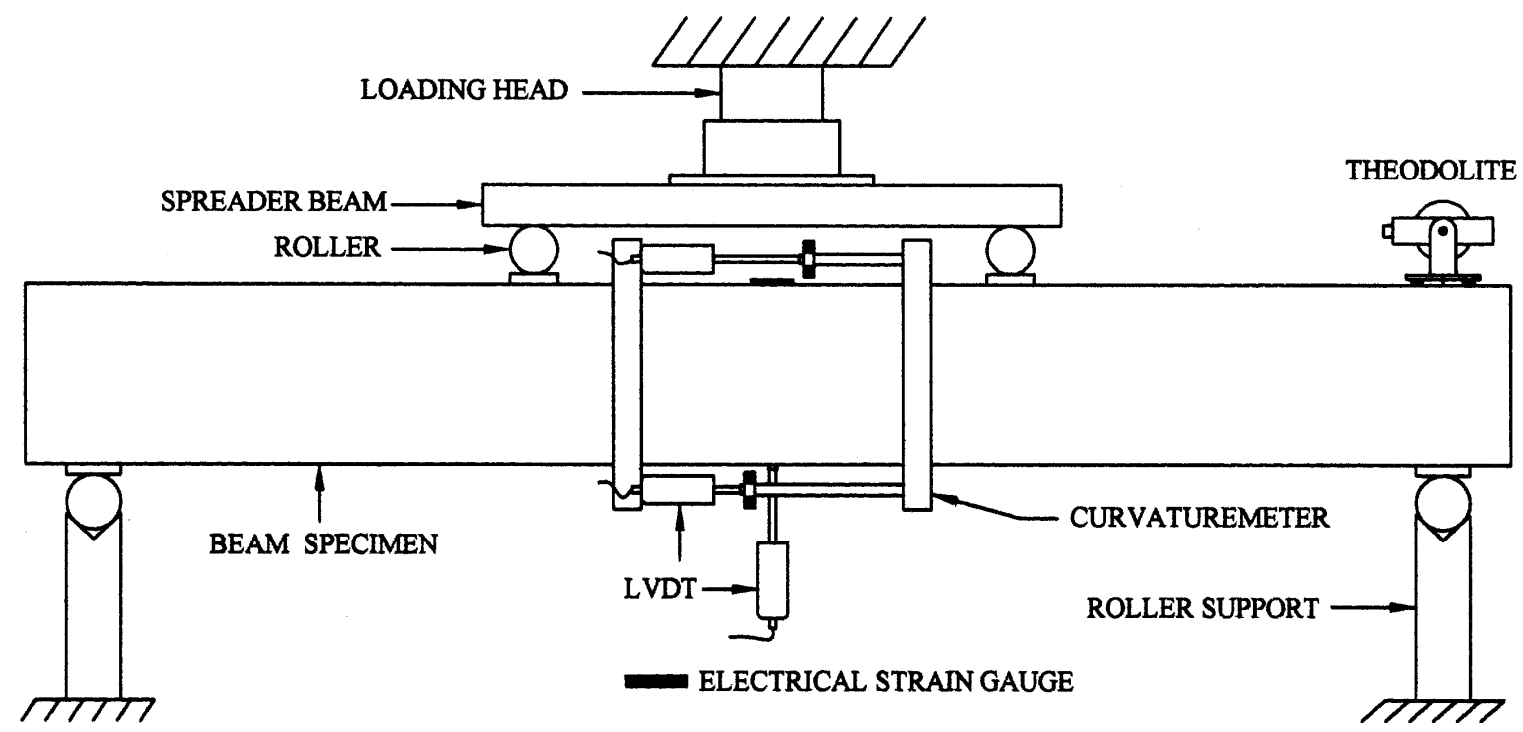

Fig. (2). Typical Loading Arrangement for the Test Beam.

CS and CSF were $74 \mathrm{~N} / \mathrm{mm}^{2}, 78 \mathrm{~N} / \mathrm{mm}^{2}$ and $88 \mathrm{~N} / \mathrm{mm}^{2}$ respectively. Although the mix CS contains binder in excess of $70 \mathrm{~kg} / \mathrm{m}^{3}$, compared with mix $\mathrm{C}$ the compressive strength increased was only about $5.5 \%$. This was possibly due to incomplete hydration since self-dessciation takes place [19].

The flexural strength of the tested prisms was about 2.98 and $3.42 \mathrm{~N} / \mathrm{mm}^{2}$. It was seen from the results that the sandstone brittieness was weil related to the filexural strength of the concrete. Furthermore, the excess total fines content led to brittleness of the concrete, thereby reducing the flexural strength of concrete. In general, the modulus of elasticity of HPC was in the range between $3.1 \times 10^{4} \mathrm{MPa}$ to $4.8 \times 10^{4}$ $\mathrm{N} / \mathrm{mm}^{2}$ or even more. But for the HPC using sandstone aggregate, the modulus of elasticity was approximately $10 \%$ lower than that of other reported studies [13-16, 20-23]. This may be due to the existing cracks and pores in the sandstone aggregate causing nonlinear behaviour of concrete at low stress level [3].
Concrete with high compressive strength and low modulus of elasticity have shown the loss in stiffness due to the existing microcracks in aggregate, that become closed during compressive loading. Others also obtained similar results for sandstone concrete [3, 24]. The modulus of elasticity of the mixes CS and CSF is slightly higher than that of the mix C. Admission of silica fume and sandstone mineral fines increased the densification of concrete as reported [25]. Thus, the modulus of elasticity substantially increased thereby lowering the strain under compression.

\section{Ultimate Moments}

The predicted ultimate moment $\left(M_{u}\right)$ was calculated based on BS 8110 [26] and ACI 318 [27], named $M_{u l t, B S} 8110$ and $M_{u l t, A C I}$ respectively. The predicted ultimate moments and the experimental yielding and ultimate moments $\left(M_{u, \text { expt }}\right)$ are shown in Table 3. At ultimate stage, the flexural strength of the beams using sandstone aggregate showed similar trend compared with other aggregates. The porosity of sandstone 
Table 2. Mechanical Properties of Companion Concrete and the Reinforcement Details of Beams

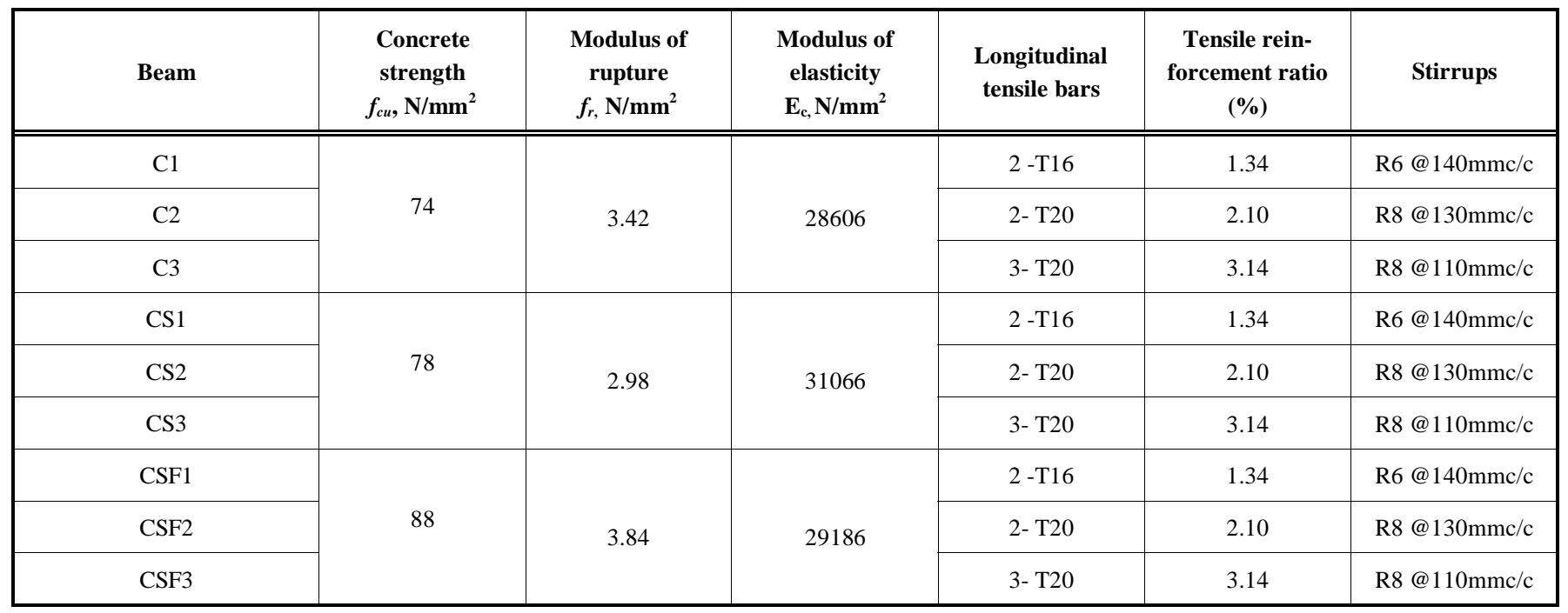

Table 3. Experimental and Predicted Ultimate Moment for the Tested Beams

\begin{tabular}{|c|c|c|c|c|c|c|c|}
\hline Beam & Age on test & $\begin{array}{c}\text { Yielding } \\
\text { moment,kNm }\end{array}$ & \multicolumn{3}{|c|}{ Ultimate Moment, kNm } & $\begin{array}{c}M_{u l t, \text { expt }} / \\
M_{u l t, B S 8110}\end{array}$ & $\begin{array}{r}M_{u l t, \text { expt }} \\
M_{u l t, A C I}\end{array}$ \\
\hline $\mathrm{C} 1$ & 48 & 38.0 & 41.90 & 36.22 & 39.95 & 1.16 & 1.05 \\
\hline $\mathrm{C} 2$ & 48 & 56.4 & 64.40 & 51.96 & 59.03 & 1.24 & 1.09 \\
\hline $\mathrm{C} 3$ & 49 & 84.0 & 90.28 & 69.67 & 83.10 & 1.30 & 1.09 \\
\hline CS2 & 51 & 59.8 & 64.40 & 52.53 & 59.41 & 1.23 & 1.08 \\
\hline $\mathrm{CS} 3$ & 52 & 84.5 & 90.28 & 70.94 & 83.93 & 1.27 & 1.08 \\
\hline CSF1 & 53 & 38.8 & 43.70 & 36.95 & 40.44 & 1.18 & 1.08 \\
\hline CSF2 & 53 & 55.5 & 62.10 & 53.72 & 60.19 & 1.16 & 1.03 \\
\hline
\end{tabular}

aggregates leads to better bond with binder. Also the sandstone aggregate allows the stress to be more uniformly distributed thereby causing the whole section contributing to strength [3]. It was pointed out by Neville [28] that the chemical interaction between siliceous aggregate and cement matrix can result in strong bonds thus increasing the strength. It was found that the beams with higher reinforcement ratio were stiffer at higher load. This may be because of the increased flexural rigidity as the concrete was confined with reinforcement. The $M_{u \text {, expt }}$ was found to be 14 to $34 \%$ and 3 to $15 \%$ higher than the $M_{u}$ based on the design codes BS 8110 [26] and ACI 318 [27] respectively. Compared to BS 8110 code provisions, the ACI code provisions give a reasonable conservative estimate. The trend in this study is similar with other findings [13-16].

\section{Deflection Characteristics}

The observed experimental mid-span deflection under service load was compared with deflection evaluated from BS 8110 [26] and ACI 318 [27]. The service load was taken as the experimental ultimate load divided by 1.7 based on ref [13]. The test results and predicted values at service load are analysed in Table 4. It was found that the effect of the compressive strength of concrete was more dominant than the effect of the steel reinforcement ratio. Higher the compressive strength lower was the deflection and higher the reinforcement ratio higher was the deflection.

The deflection at service load for the beam $\mathrm{C}$ was slightly higher than that of beam CS and beam CSF. The crushed stone fillers weakened the frontier zones between the brittle material components [29]. The weaker bond in the transition zone allowed cracks around the aggregates with better energy dissipation, and the failure under compression did not react so explosively. Also addition of high reactivity pozzolans like silica fume in concrete improved the interfacial zone. In consequence, the brittleness of the concrete increased [24]. The reduction of the amount of pozzolan or the application of a less reactive pozzolan like fly ash could increase the ductility as observed. It was understood from the 
Table 4. Deflection Characteristics for the Tested Beams

\begin{tabular}{|c|c|c|c|c|c|c|c|}
\hline Beam & Service load, kN & \multicolumn{3}{|c|}{ Deflection, mm } & $\begin{array}{c}\boldsymbol{\delta}_{\text {ser,expt }} / \\
\boldsymbol{\delta}_{\text {ser,BS 8110 }}\end{array}$ & $\begin{array}{c}\boldsymbol{\delta}_{\text {ser,expt }} / \\
\boldsymbol{\delta}_{\text {ser, }, A C I}\end{array}$ & $\begin{array}{l}\text { Span / } \\
\boldsymbol{\delta}_{\text {ser,expt }}\end{array}$ \\
\hline $\mathrm{C} 2$ & 65.88 & 15.93 & 14.01 & 13.19 & 1.14 & 1.21 & 188.32 \\
\hline $\mathrm{C} 3$ & 92.36 & 15.16 & 14.76 & 14.17 & 1.03 & 1.07 & 197.88 \\
\hline CS2 & 65.88 & 15.91 & 13.69 & 12.88 & 1.16 & 1.24 & 188.56 \\
\hline $\mathrm{CS} 3$ & 93.52 & 15.28 & 14.36 & 13.77 & 1.06 & 1.11 & 196.34 \\
\hline CSF1 & 44.71 & 12.92 & 13.39 & 12.10 & 0.96 & 1.07 & 223.19 \\
\hline
\end{tabular}

Table 5. Cracking Behaviour of the Tested Beams

\begin{tabular}{|c|c|c|c|c|c|c|}
\hline Beam & $\begin{array}{l}\text { Service } \\
\text { load, kN }\end{array}$ & \multicolumn{3}{|c|}{ Crack width $\omega_{\max }, \mathrm{mm}$} & $\begin{array}{c}\omega_{\max , \exp } / \\
\omega_{\max , B S 8110}\end{array}$ & $\begin{array}{l}\omega_{\max , \exp } \\
\omega_{\max , A C l}\end{array}$ \\
\hline $\mathrm{C} 2$ & 65.88 & 0.223 & 0.181 & 0.282 & 1.23 & 0.79 \\
\hline $\mathrm{C} 3$ & 92.36 & 0.225 & 0.183 & 0.244 & 1.23 & 0.92 \\
\hline $\mathrm{CS} 2$ & 65.88 & 0.244 & 0.178 & 0.281 & 1.37 & 0.87 \\
\hline $\mathrm{CS} 3$ & 93.52 & 0.181 & 0.183 & 0.244 & 0.99 & 0.74 \\
\hline CSF1 & 44.71 & 0.237 & 0.190 & 0.285 & 1.25 & 0.83 \\
\hline CSF2 & 63.53 & 0.194 & 0.173 & 0.271 & 1.12 & 0.71 \\
\hline
\end{tabular}

results that substitution of crushed sandstone aggregates with sandstone fillers in HPC exhibited ductile behaviour.

At given concrete strength, a sudden increase in deflection was observed just prior to failure for the beams C1, CS1 and CSF1. This may be because the steel was beginning to yield and ultimately the beams reached their maximum load capacity. However, the beams with low tensile reinforcement ratio underwent relatively more deflections compared to beams with higher ratio. It indicated that increasing reinforcement ratio decreases deflection ductility. In other words greater ductility can be achieved with lesser reinforcement ratio. However, this result is similar to other findings [30].

The average ratio of experimental deflection to the predicted deflection was found to be 1.11 and 1.18 based on BS 8110 [26] and ACI 318 [27] respectively. From the analysis, it was found that there is a close agreement between predicted and experimental deflections. However, it was shown by Rashid and Mansur [13] that the inclusion of associated shrinkage and creep effect dramatically improved the predicted values based on BS 8110 [26] and ACI 318 [27] has limited the total deflection to span/250 including the effects of creep and shrinkage. However, the denominator observed under service load was in the range from 188 to 240 . These measured deflections were based on short term loading and did not allow any time dependent increase due to shrinkage and creep [13, 14]. Also, the effect of aggregate porosity decreased the tensile stiffness of concrete and probably increased the deflection.

\section{Cracking Behaviour}

Table 5 gives the measured crack width (interpolated values) at the service load and the crack width calculated based on codes BS 8110 [26] and ACI 318 [27]. The maximum crack width observed at service load varied from 0.15 $\mathrm{mm}$ to $0.24 \mathrm{~mm}$ and it is well within the durability requirements as per BS 8110 [26] and ACI 318 [27]. Analyzed results showed that both codes overestimated the crack width at the center of the tensile reinforcement level. The equations recommended in both codes are too sensitive to concrete cover. Any variation in concrete cover leads too much greater increase in crack width. As observed, all the beams 
Table 6. Characteristics of Crack Spacing and Crack Height

\begin{tabular}{|c|c|c|c|c|c|c|c|}
\hline \multirow[t]{3}{*}{ Beam } & \multicolumn{3}{|c|}{$\begin{array}{c}\text { Characteristics of Crack Between } \\
\text { Loading Points }\end{array}$} & \multicolumn{2}{|c|}{ Crack in Span } & \multirow{3}{*}{$\begin{array}{c}\text { Calcul. } \\
\text { crack spacing } \\
S_{r m, \text { calcu. }} \mathbf{m m}\end{array}$} & \multirow{3}{*}{$\begin{array}{l}S_{r m, \text { expt }} / \\
S_{\text {rm, calcu. }}\end{array}$} \\
\hline & \multirow{2}{*}{$\begin{array}{l}\text { No. } \\
\text { of crack }\end{array}$} & \multirow{2}{*}{ Height } & Crack spacing, mm & \multirow{2}{*}{ No. of cracks } & \multirow{2}{*}{$\begin{array}{c}\text { Average crack } \\
\text { spacing } \\
S_{r m, \text { expt }}, \mathrm{mm}\end{array}$} & & \\
\hline & & & Range (mm) & & & & \\
\hline $\mathrm{C} 1$ & 9 & 165 & 37 to 145 & 20 & 103 & 91.79 & 1.12 \\
\hline $\mathrm{C} 3$ & 9 & 153 & 46 to 165 & 26 & 97 & 83.42 & 1.16 \\
\hline $\mathrm{CS} 1$ & 10 & 171 & 45 to 149 & 25 & 109 & 91.79 & 1.19 \\
\hline $\mathrm{CS} 2$ & 9 & 155 & 25 to 172 & 28 & 84 & 83.42 & 0.99 \\
\hline $\mathrm{CS} 3$ & 9 & 136 & 40 to 215 & 30 & 97 & 83.42 & 1.16 \\
\hline CSF3 & 9 & 158 & 65 to 170 & 29 & 98 & 83.42 & 1.17 \\
\hline
\end{tabular}

exhibited vertical cracks known as flexural cracks in the pure bending region before failure. The crack propagation outside the pure bending region was similar to flexural cracks. However, this is similar to other findings on beams [14-16] made with compressive strength of concrete greater than 50 $\mathrm{N} / \mathrm{mm}^{2}$.

Normally, the reinforcement ratios significantly control the crack width for flexural members. The results here showed that the aggregate-mortar matrix strongly influences the crack width. Although the chemical interaction between the reactive aggregate and binder may result in stronger bond, the porosity of the aggregate forms a weaker link in the interfacial transition zone. As a result, the cracks were developed in the interface around the aggregates-mortar. However, because of the addition of silica fume and fly ash, the interaction between the reactive aggregates and mortar in the interface zone becomes stronger [25, 31]. In consequence, the cracks pass through the aggregate. It is quite clear from the results that the crack width shown increased with rougher surfaces and decreased with stronger mortars.

Generally, the risk of crack formation in HPC with low ductility is high. At given strength, the increase in tensile reinforcement ratio in the beam $\mathrm{C}$ showed only little difference. In the beam CSF, as the reinforcement ratio increased the crack width gradually reduced. For the same reinforcement ratio, the beam CS1 showed less crack width compared to beam $\mathrm{C} 1$. As a result of addition of silica fume, the concrete became more brittle and increased the total cracks as shown in Table 6. In consequence, the crack width varied significantly.

\section{Characteristics of Crack Spacing and Crack Height}

Formation of cracks and crack characteristics are an important indication about how the flexural members would behave at service loads. Table $\mathbf{6}$ summarises the results of crack characteristics between the loaded points and in the span. The theoretical crack spacing $\left(S_{r m}\right.$, calcu. $)$ was calculated according to CEB-EC2 equation [15] and the ratio to the average experimental crack spacing $\left(S_{r m}\right.$ expt $)$ is shown in Table 6. The crack height at middle of beam gradually decreased with the increased amount of tensile reinforcement. At failure, the flexural cracks penetrated the compression zone and reached the crushing zone of the beam. The average depth of crushed concrete was found to vary between 20$55 \mathrm{~mm}$ for different tensile reinforcement ratios. The maximum and minimum crack spacing between the loaded points varied from 140 to $215 \mathrm{~mm}$ and 25 to $65 \mathrm{~mm}$ respectively for all the beams. The ratio of $S_{r m, \text { expt }}$ to $S_{r m \text {, calcu }}$ were found to be 0.99 to 1.21 and it reasonably agrees with the experimental values. It is confirmed that aggregate-mortar matrix in the transition zone influences the maximum and minimum crack spacing.

The porosities appearing in sandstone develop better bond and therefore less numbers of cracks in the beam $\mathrm{C}$. The numbers of cracks in the beams CS and CSF were more, probably due to incomplete hydration of mineral admixtures, especially fly ash at early age. Hwang et al., [32] reported that silica fume decreased the bond strength in high performance concrete with a ratio of water- cementitious materials in the range of 0.28 to 0.33 . This is in agreement with the tested beams. This result suggests that structural members made with higher fines were more brittle and lost the bond strength gradually at applied load.

\section{Cracking Moment and Cracking Moment of Inertia}

Table 7 gives the experimental moment at crack $\left(M_{c r}\right.$ expt $)$ and the predicted cracking moment $\left(M_{c r}\right.$, theo $)$. The obtained ratio of the $M_{c r}$, theo to the corresponding $M_{c r}$, expt was varied from 1.02 to 2.41 . It was pointed out by many authors that the reactive aggregate in concrete has much more detrimental effect on the mechanical properties of concrete than the structural behavior of reinforced concrete beams. However, Koyangi et al., [33] demonstrated that the concrete using reactive aggregate with tensile reinforcement ratio exceeding $2 \%$ experienced nearly twice the cracking loads of unaffected concrete. This may be due to the internal restraint 
Table 7. Experimental and Predicted Cracking Moment and Cracking Moment Of Inertia

\begin{tabular}{|c|c|c|c|c|c|c|c|c|}
\hline \multirow{2}{*}{ Beam } & \multicolumn{2}{|c|}{$\begin{array}{c}\text { Cracking moment } \\
\qquad M_{c r}, \mathrm{kNm}\end{array}$} & \multirow{2}{*}{$\begin{array}{c}M_{c r \text { expt }} t \\
M_{\text {crstheo }}\end{array}$} & \multicolumn{3}{|c|}{$\begin{array}{l}\text { Moment of inertia } \\
\qquad I_{c r}, \times 10^{6} \mathrm{~mm}^{4}\end{array}$} & \multirow{2}{*}{$\begin{array}{c}\boldsymbol{I}_{c r}, \text { expt } 1 / \\
\boldsymbol{I}_{c r}, \text { theo }\end{array}$} & \multirow{2}{*}{$\begin{array}{c}I_{c r}, \text { expt } 2 / \\
I_{c r}, \text { theo }\end{array}$} \\
\hline & $\boldsymbol{M}_{\text {cro expt. }}$ & $M_{c r \text { theo }}$ & & $I_{c r}$, exptI & $I_{c r}, e_{\text {expt } 2}$ & $I_{c r}$, theo & & \\
\hline $\mathrm{C} 1$ & 5.46 & 4.72 & 1.16 & 54.79 & 61.99 & 65.55 & 0.84 & 0.95 \\
\hline $\mathrm{C} 2$ & 10.35 & 4.72 & 2.19 & 74.87 & 95.16 & 90.18 & 0.83 & 1.06 \\
\hline CS1 & 4.60 & 4.11 & 1.12 & 54.61 & 65.02 & 61.57 & 0.89 & 1.06 \\
\hline CS2 & 8.05 & 4.11 & 1.96 & 66.01 & 77.21 & 85.07 & 0.78 & 0.91 \\
\hline $\mathrm{CS} 3$ & 9.66 & 4.11 & 2.34 & 92.18 & 112.8 & 111.65 & 0.83 & 1.01 \\
\hline CSF1 & 5.38 & 5.3 & 1.02 & 50.8 & 56.59 & 64.69 & 0.79 & 0.87 \\
\hline
\end{tabular}

Table 8. Ductility and End Rotations for the Tested Beams

\begin{tabular}{|c|c|c|c|c|c|c|c|}
\hline Beam & \multicolumn{2}{|c|}{ At yielding } & \multicolumn{2}{|c|}{ At ultimate } & $\begin{array}{c}\boldsymbol{\mu}_{\delta}= \\
\boldsymbol{\delta}_{\mathbf{u}} / \boldsymbol{\delta}_{\mathbf{y}}\end{array}$ & $\begin{array}{c}\mu_{\varphi}= \\
\varphi_{\mathrm{u}} / \varphi_{\mathrm{y}}\end{array}$ & $\begin{array}{c}\text { End rotation } \\
\text { (degrees) }\end{array}$ \\
\hline $\mathrm{C} 1$ & 21.90 & 0.021 & 49.48 & 0.075 & 2.26 & 3.51 & $2^{\circ} 26^{\prime} 24^{\prime \prime}$ \\
\hline $\mathrm{C} 2$ & 23.80 & 0.021 & 42.02 & 0.049 & 1.77 & 2.35 & $2^{\circ} 10^{\prime} 48^{\prime \prime}$ \\
\hline CS1 & 19.62 & 0.018 & 44.28 & 0.059 & 2.26 & 3.21 & $2^{\circ} 17^{\prime} 24^{\prime \prime}$ \\
\hline $\mathrm{CS} 2$ & 26.87 & 0.025 & 35.96 & 0.035 & 1.34 & 1.39 & $1^{\circ} 54^{\prime} 00^{\prime \prime}$ \\
\hline $\mathrm{CS} 3$ & 26.90 & 0.024 & 31.26 & 0.029 & 1.16 & 1.21 & $1^{\circ} 41^{\prime} 24^{\prime \prime}$ \\
\hline CSF1 & 23.68 & 0.024 & 54.20 & 0.080 & 2.29 & 3.40 & $2^{\circ} 20^{\prime} 24^{\prime \prime}$ \\
\hline
\end{tabular}

caused by the tensile reinforcement in the reinforced concrete beams. Probably this may be the reason for variation in cracking moment. However, more data on flexural behavior using sandstone aggregate are needed to clarify this discussion.

The experimental moment of inertia $I_{c r}$, exptl and $I_{c r}$, expt2 were calculated based on equation shown in Ref [16]. The calculation of $I_{c r}$, exptI depends on deflection corresponding to the load that causes yielding in the steel reinforcement. Similarly, $I_{c r}$, expt2 can be defined as the slope of the initial yielding of tensile reinforcement in the moment-curvature curve. Differences in values of $I_{c r}$, exptl and $I_{c r}$, expt2 are expected due to the variation in deflection and curvature distribution along the beam (Table 8). The theoretical moment of inertia $I_{c r}$, theo is based on the traditional approach using cracked transformed section. The calculated values of $I_{c r}$, expt1, $I_{c r}$, expt2 and $I_{c r}$, theo are given in Table 7 .
The result shows that the $I_{c r}$, theo is 10 to $22 \%$ higher compared with $I_{c r}$, exptl. The trend observed from results was that the $I_{c r}$, theo increased (expect for beams CS3 and CSF3) as the deflection at yield $\left(\delta_{\mathrm{y}}\right)$ decreased. This result suggests that the loss of stiffness caused by sandstone aggregate greatly influenced the moment of inertia. However, the $I_{c r}$ based on moment-curvature is in reasonable agreement with theoretical $I_{c r}$. As mentioned earlier, this may be because the detrimental effect caused by aggregate in concrete was compensated with the tensile reinforcement.

\section{Ductility Indexes}

The term ductility is defined as the ability of the material or member to sustain deformation beyond the elastic limit, while maintaining a reasonable load-carrying capacity before total collapse. Ductility is measured by the ratio called ductility index $(\mu)$ and it is usually expressed as a ratio of deflection $(\Delta)$, and curvature $(\varphi)$ at ultimate to the corresponding 
Table 9. $x / d$ Ratio and Strain Values for the Tested Beams

\begin{tabular}{|c|c|c|c|c|c|}
\hline Beam & $\begin{array}{c}\text { Experimental } \\
\text { Ultimate } \\
\text { Load }(\mathbf{k N})\end{array}$ & $x / d,_{\text {expt }}$ & $\begin{array}{c}x / d,,_{\text {expt }} / \\
x^{\max } / d\end{array}$ & $\begin{array}{c}\text { *Concrete } \\
\text { compressive strain } \\
\text { (micro strain) }\end{array}$ & $\begin{array}{l}\text { *Tensile steel strain } \\
\text { (micro strain) }\end{array}$ \\
\hline $\mathrm{C} 2$ & 112 & 0.41 & 0.82 & 4730 & 5055 \\
\hline $\mathrm{C} 3$ & 157 & 0.47 & 0.94 & 5328 & 4769 \\
\hline $\mathrm{CS} 2$ & 112 & 0.35 & 0.70 & 3820 & 6885 \\
\hline CS3 & 159 & 0.42 & 0.84 & 5115 & 5025 \\
\hline CSF1 & 76 & 0.34 & 0.68 & 3567 & 6598 \\
\hline
\end{tabular}

property at yield $[16,34]$. The yield and ultimate values of deflection and curvature were obtained from the curves of load vs deflection and load vs curvature. Table $\mathbf{8}$ presents the values of deflection ductility $\left(\mu_{\delta}\right)$ and curvature ductility $\left(\mu_{\varphi}\right)$. At given concrete strength, the deflection ductility decreased as the tensile reinforcement ratio increased. The observed deflection ductility in this study was between 1.16 and 2.29. In general, the deflection ductility in the range of 3 to 5 is considered imperative for adequate ductility [16]. However, tested beam results showed that the deflection ductility was inadequate to redistribute the moment. Increasing compressive reinforcement ratio would be more beneficial to obtain adequate ductility.

The curvature ductility demands the plastic hinge mechanism by limiting the amount of tension and compression reinforcement. Park and Ruitong [35] pointed out that for flexural members to ensure general design requirements, the curvature ductility should be greater than 2 and the requirements to ensure for moment redistribution should be greater than 4. Also the same authors reported that the curvature ductility decreased as the tension reinforcement $(\rho)$ increased and compression reinforcement $\left(\rho^{\prime}\right)$ decreased. Since $\rho^{\prime}$ is fixed for all beams, the increase or decrease in curvature ductility with respect to $\rho^{\prime}$ is not considered for discussions. The observed curvature ductility was between 1.21 and 3.51. The results showed that, curvature ductility decreased as the tensile reinforcement increased. However, the effect of aggregate porosity may change curvature ductility significantly. It was found that the ductility increased with aggregate porosity and decreased with stronger mortar, especially silica fume in the beam CS. At low tensile reinforcement ratio $(1.34 \%)$ the tested beams showed adequate curvature ductility. The same trend was also reported by Chien et al. [36].

The average values of end rotations of the tested beams just prior to failure varied from $1^{\circ} 41^{\prime} 24^{\prime \prime}$ to $2^{\circ} 26^{\prime} 24^{\prime \prime}$ as shown in Table $\mathbf{8}$. Test results showed that the tensile reinforcement and the mineral admixtures in concrete reduced the end rotation before crack development. Lower the end rotation better was the flexural rigidity. It was pointed out by Elbardy and Ghali [37] that the rigidity of a member depended on the tension stiffening of concrete. Also they pointed out that the end rotation gradually decreased with an appearance of cracks until cracking reached a stabilized pattern.

\section{Neutral Axis and Strain}

Neutral axis (NA) depth was obtained from the strain distribution, which was measured experimentally at the compression concrete and at the tension reinforcement. The ratio of experimental NA $\left(x / d_{\text {expt }}\right)$ to the predicted NA $\left(x^{\max } / d\right)$ (the value 0.5 was taken as $x^{\max } / d$ as recommended in BS 8110 [26] at ultimate limit state) were analysed and presented in Table 9. It was shown from test results that for a given concrete strength, the neutral axis depth increased as tensile reinforcement ratio increased. The lower reinforcement ratio ensured that the depth of NA was lower leading to ductile failure. The NA moved nearer to the top of beam with an increase in compressive strength of concrete as observed in this study. This trend was similar to other reported studies on beams using concrete compressive strength greater than $50 \mathrm{~N} / \mathrm{mm}^{2}$ [38].

The recorded strains of compressive concrete and tensile steel were in the range of 2565 to $5328 \mu \mathrm{s}$ and 4769 to 6885 $\mu s$ (micro strain) respectively. These values were relatively higher when compared with HPC using nonreactive aggregates [35]. As mentioned earlier, the high porosity sandstone resulted in the distinct concavity of the deformation curves at low stress levels and in strain hardening as the level of stress increased. The mineralogy and texture of sandstone may also have influenced the elastic modulus and may have played a certain role on the observed nonlinear behaviour of strains [3]. Swamy et al [17] pointed out that the reactive aggregate in singly reinforced concrete beam caused high differential expansion between top and bottom fibers and led to increased strains. 


\section{CONCLUSIONS}

Experimental investigation and theoretical prediction of the flexural behaviors of beams are presented in this paper. HPC made with reactive sandstone maintains the structural integrity much better if sandstone fillers are used. Based on this study, the following conclusions were made:

1. Mechanical properties of concrete such as compressive strength and modulus of elasticity increased with addition of SF and FA. Crushed sandstone aggregate with sandstone fillers improved the ductility of concrete. At the same time increasing higher fines decreased the modulus of rupture of concrete.

2. The ultimate moment for sandstone concrete beams were comparable with concrete beams made of other aggregates.

3. The short-term deflections observed at service loads were quite above the allowable values. However, further investigations on creep and shrinkage are needed to confirm this statement.

4. The maximum crack width observed at service load varied from 0.15 to $0.24 \mathrm{~mm}$ and it was well within the durability requirements as per BS8110 and ACI 318 code. It was found that the addition of SF and FA reduced the crack width significantly.

5. The ratio of experimental cracking moment to theoretical cracking moment was found to be 1.02 to 2.41. This result implies that the internal restraint caused by the tensile reinforcement greatly influenced the cracking load.

6. The existing cracks and pores in the aggregate greatly affected the deflection ductility and curvature ductility. However, at low tensile reinforcement ratio $(1.34 \%)$ both these ductility indices were found to be adequate to ensure the general design requirements for flexural members.

7. The significant nonlinear behavior of concrete can be attributed to the viscoelastic properties of sandstone aggregate [3]. Microcracks initiated in the interfaces, and the strain increased at a faster rate than the applied stress.

\section{ACKNOWLEDGEMENT}

This project is funded by Ministry of Science, Technology and Innovation, Malaysia under IRPA research grant no.03-02-10-0033-EA0031. Sincere thanks are extended to Prof. H. Achyutha who has given fruitful suggestions for this study.

\section{REFERENCES}

[1] M. Prezzi, P. J. M. Monteiro, and G. Sposito, "The alkali-silica reaction. Part I: Use of the double-layer theory to explain the behavior of reaction-product gels", ACI Mat. J., vol. 94, pp. 10-18, January 1997.

[2] J. Collins, and P.D. Bareham, "Alkali-silica reaction: Suppression of expansion using porous aggregate", Cem. Concr. Res., vol. 17, pp. 89-96, January 1987.

[3] W. Baalbaki, B. Benmokrane, O. Chaallal, and P.C. Aitcin, "Influence of coarse aggregate on elastic properties of high performance concrete", ACI Mat. J., vol. 88, pp. 499-503, Sept. 1991.

[4] A. M. Neville, "Aggregate bond and modulus of elasticity of concrete", ACI Mat. J., vol. 94, pp. 71-74, Jan. 1997.
R. P. Khatri, and V. Sirivivatnanon, "Effect of different supplementary cementitious materials on mechanical properties of high performance concrete", Cem. Concr. Res., vol. 25, pp. 209-220, January 1995.

[6] A. A. Almusallam, H. Beshr, M. Maslehuddin, and O.S.B. AlAmoudi, "Effect of silica fume on the mechanical properties of low quality coarse aggregate concrete", Cem. Concr. Compo., vol. 26, pp. 891-900, October 2004.

[7] J. Collins, and P. D. Bareham, "Alkali-silica reaction: Suppression of expansion using porous aggregate", Cem. Concr. Res., vol. 17, pp. 89-96, Jan. 1987.

[8] S. P. Shah, and S. H. Ahmad, "High Performance Concretes and Applications", First edition, Edward Arnold, Great Britain, 1994.

[9] H. Chen, J. A Soles, and V. M. Malhotra, "Investigations of supplementary cementing materials for reducing Alkali-Aggregate Reactions", Cem. Concr. Compo., vol. 15, pp. 75-84, Feb. 1993.

[10] M. D. A. Thomas, M. H. Shehata, S. G. Shashiprakash, D. S. Hopkins, and K. Cail, "Use of ternary cementitious systems containing silica fume and fly ash in concrete", Cem. Concr. Res., vol. 29, pp. 1207-1214, Aug. 1999.

[11] H. Marzouk, and S. Langdon, "The effect of alkali-aggregate reactivity on the mechanical properties of high and normal strength concrete", Cem. Concr. Compo., vol. 25, pp. 549-556, May-July 2003.

[12] P. S. Kumar, M. A. Mannan, V. J. Kurian, and H. Achyutha, "Effect of crushed sandstone sand on the properties of high performance concrete" J. Civil Eng. Res. Pract., vol. 2, pp. 1-11, Jan. 2005.

[13] M. A. Rashid, and M. A. Mansur, "Reinforced high strength concrete beams in flexure", ACI Struct. J., vol. 102, pp. 462-471, MayJune 2005

[14] R. N. Swamy and K. L. Anand, "Structural behaviour of high strength concrete beams", Building Science, vol. 9, pp. 131-142, Feb. 1974.

[15] S. Sarkar, O. Adwan, and J.G.L. Munday, "High strength concrete: an investigation of the flexural behaviour of high strength RC beams", Struct. Eng., vol. 75, pp. 115-121, April 1997.

[16] S. A. Ashour, "Effect of compressive strength and tensile reinforcement ratio on flexural behaviour of high strength concrete beams", Eng. Struct., vol. 22, pp. 413-423, May 2000.

[17] R. N. Swamy, and M. M. Al-Asali, "Effect of Alkali-Silica Reaction on the Structural Behavior of Reinforced Concrete Beams", Proceeding of the ACI Struct. J., vol. 86, pp. 451-459, July 1989.

[18] S. Fan, and J. M. Hanson, "Effect of alkali silica reaction expansion and cracking on structural behavior of reinforced concrete beams", ACI Struct. J., vol. 95, pp. 498-505, May 1998.

[19] H. Toutanji, N. Delatte, S. Aggoun, R. Duval, and A. Danson, "Effect of supplementary cementitious materials on the compressive strength and durability of short-cured concrete", Cem. Concr. Res., vol. 34, pp. 311-319, Feb. 2004.

[20] P. C. Aitcin, and P. K. Mehta, "Effect of coarse aggregate characteristics on mechanical properties of high performance concrete", ACI Mat. J., vol. 87, pp. 103-107, Feb. 1990.

[21] F.P. Zhou, F. D. Lydon, and B. I. G. Barr, "Effect of coarse aggregate on elastic modulus and compressive strength of high performance concrete", Cem. Concr. Res., vol. 25, pp. 177-186, Jan. 1995.

[22] K. R. Wu, B. Chen, W. Yao, and D. Zhang, "Effect of coarse aggregate type on mechanical properties of high performance concrete", Cem. Concr. Res., vol. 31, pp. 1421-1425, Oct. 2001.

[23] M. G. Alexander, "Aggregates and the Deformation Properties of Concrete", ACI Mat. J., vol. 93, pp. 1-9, June 1996.

[24] O. Sengul, C. Tasdemir and M. A. Tasdemir, "Influence of aggregate type on mechanical behaviour of normal and high strength concretes", ACI Mat. J., vol. 99, pp. 367-374, June 2002.

[25] T. B. Aulia, and K. Deutschmann, "Effect of mechanical properties of aggregate on the ductility of high performance concrete", Lacer Leipzig, vol. 4, pp. 133-148, April 1999.

[26] British Standards Institution. BS 8110, Part 1: Code of practice for design and construction, Part 2: Code of practice for special circumstances, BSI, London, 2000.

[27] American Concrete Institute. Building Code Requirements for Structural Concrete, ACI, Farmington Hills, ACI 318-02, 2002.

[28] A. M. Neville, Properties of concrete, Fourth edition, Pearson Education Limited, London, 2002. 
[29] V. Penttala, and J. Komonen, "Effects of aggregates and microfillers on the flexural properties of concrete", Magazine Concr. Res., vol. 49, No.179, pp. 81-97, June 1997.

[30] T. Ahmed, E. Burley, and S. Rigden, "Effect of Alkali-Silica Reaction on tensile bond strength of reinforcement in concrete tested under static and fatigue loading", ACI Mat. J., vol. 96, pp. 419-428, April 1999.

[31] E. I. Yang, S. Morita, and T. Y. Seong, "Effect of axial restraint on mechanical behavior of high-strength concrete beams ", ACI Struct. J., vol. 97, pp. 751-756, May 2000.

[32] S. Hwang, Y. Lee, and C. Lee, "Effect of silica fume on the splice strength of deformed bars of high-performance concrete", ACI Struct. J., vol. 91, pp. 294-302, March 1994.

[33] W. Koyangi, K. Rokugo, and Y. Uchida, "Mechanical properties of concrete deteriorated by alkali-aggregate reaction under various reinforcement ratios", Proceedings of the $9^{\text {th }}$ International Confer- ence on Alkali-Aggregate Reaction, London, England, pp. 556-563, July 1992.

[34] M. Pecce, and G. Fabbrocino, "Plastic rotation capacity of beams in normal and high-performance concrete", ACI Struct. J., vol. 96, pp. 290-296, Feb. 1999.

[35] R. Park, and D. Ruitong, "Ductility of doubly reinforced concrete beam sections", ACI Struct. J., vol. 85, pp. 217-225, March-April 1988.

[36] C.H. Lin, and F.S. Lee, "Ductility of high performance concrete beams with high strength lateral reinforcement", ACI Struct. J., vol. 98, pp. 600-607. April 2001.

[37] M. Elbadry, and A. Ghali, "Control of thermal cracking of concrete structures", ACI Struct. J., vol. 92, pp. 435-450, July 1995.

[38] L.F.A. Bernardo, and S.M.R. Lopes, "Neutral axis depth versus flexural ductility in high strength concrete beams", ASCE J. Struct. Eng., vol. 130, pp. 452-459, March 2004. 